\title{
Physiochemical quality and nutritional value of ensiled fresh maize stover and groundnut haulms in wet season for sustainable ruminant production
}

Lamidi, A. A. and Ingweye, J. N.

Department of Animal Science, University of Port Harcourt, Port Harcourt, Rivers State, Nigeria

Correspondent author: akeem.lamidi@uniport.edu.ng;+2348055219133 /

Abstract

08103142367

The study was conducted to evaluate the physiochemical quality and nutritional value of ensiled fresh maize stover and groundnut haulms for wet season sustainable ruminant production. Fresh maize stover and fresh groundnut haulms were collected, wilted for 3-4 days, chopped and ensiled in different proportions to make three (3) experimental treatments (T1: 100\% maize stover; T2:100\% groundnut haulms; T3:50\% maize stover and 50\% groundnut haulms) and replicated four (4) times in glass Bamma ${ }^{\circledR}$ bottles for 30 days. Physical features, proximate composition, mineral profile, anti-nutritional factors, post invitro digestibility characteristics and nutritional values of the silages were examined. Results showed that the colour of the silage were cream, greenish brown and light brown for T1, T2 and T3, respectively. Texture was smooth for T1, coarse for T2 and slightly coarse for T3. All the silages were moist with pleasant aroma. The $\mathrm{pH}$ and temperature value ranges from $3-$ $4.5,30-31.5^{\circ} \mathrm{C}$, respectively. There were significant differences $(P<0.05)$ in the proximate composition, fiber fractions, minerals, anti-nutritional factors and the post in-vitro digestibility characteristics of the silages. Silage T3 (50\% maize stover and $50 \%$ groundnut haulms) had highest $(P<0.05)$ significant content for the parameters considered. Similar $(P>0.5)$ nutritive value (Dry matter intake (DMI), digestible dry matter (DDM), and relative feed value $(R F V))$ were recorded for the experimental treatments. The values observed for $D M I, D D M$ and RFV ranged from 2.44 - 2.45, 67.62 - 67.67 and 127.86 - 127.98, respectively. Conclusively, the silage exhibited good physiochemical quality and nutritional value that justified its potential in solving the challenges of dry season feeding. Treatment 3 (50\% maize stover and 50\% groundnut haulms) is recommended for ruminant farmers.

Keywords: Groundnut-haulms, maize-stover, physiochemical, qualities, ruminant, silage,

La Qualité physiochimique et valeur nutritionnelle des tiges de maïs frais ensilées et des fanes d'arachide en saison humide pour une production durable de ruminants

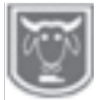

Résumé

L'étude a été menée pour évaluer la qualité physico-chimique et la valeur nutritionnelle des tiges de maïs frais ensilées et des fanes d'arachide pour la production durable de ruminants en saison humide. Les tiges de maïs frais et les fanes d'arachide fraîches ont été collectées, fanées pendant 3 à 4 jours, hachées et ensilées dans des proportions différentes pour faire trois (3) traitements expérimentaux (T1 : 100\% de tiges de maïs ; T2 : 100\% de fanes d'arachide ; T3 : 50\% tiges de maïs et 50\% de fanes d'arachide) et répliquées quatre (4) fois dans des bouteilles en verre Bamma ${ }^{\circledR}$ pendant 30 jours. Les caractéristiques physiques, la composition immédiate, le profil minéral, les facteurs anti-nutritionnels, les caractéristiques de digestibilité post-in vitro et les valeurs nutritionnelles des ensilages ont été examinés. Les 
résultats ont montré que la couleur de l'ensilage était crème, brun verdâtre et brun clair pour T1, T2 et T3, respectivement. La texture était lisse pour T1, grossière pour T2 et légèrement grossière pour T3. Tous les ensilages étaient humides avec un arôme agréable. La valeur du $\mathrm{pH}$ et de la température varie respectivement de 3 à 4,5 et 30 à $31,5^{\circ} \mathrm{C}$. Il y avait des différences significatives $(P<0,05)$ dans la composition immédiate, les fractions de fibres, les minéraux, les facteurs anti-nutritionnels et les caractéristiques de digestibilité post-invitro des ensilages. L'ensilage T3 (50\% de tiges de maïs et 50\% de fanes d'arachide) avait la teneur significative la plus élevée $(P<0,05)$ pour les paramètres considérés. Des valeurs nutritives similaires $(P>0,5)$ (ingestion de matière sèche (DMI), matière sèche digestible $(D D M)$ et valeur d'alimentation relative $(R F V)$ ) ont été enregistrées pour les traitements expérimentaux. Les valeurs observées pour le 'DMI', le 'DDM' et le 'RFV' allaient respectivement de 2,44 à 2,45, 67,62 à 67,67 et 127,86 à 127,98. En conclusion, l'ensilage présentait une bonne qualité physico-chimique et une valeur nutritionnelle qui justifiaient son potentiel à résoudre les défis de l'alimentation en saison sèche. Le traitement $3(50 \%$ de tiges de maïs et $50 \%$ de fanes d'arachide) est recommandé pour les éleveurs de ruminants.

Mots clés : arachide-fanes, tiges de maïs, physicochimiques, qualités, ruminant, ensilage,

\section{Introduction}

Natural pasture is known to be the main source of feed for ruminant livestock production in Nigeria, as most famers can hardly afford to keep their animals on concentrate rations (Lamidi et al., 2019a). Lamidi et al. (2009) reported that available forage for most part of the year is low in crude protein, thus leads to marked decrease in voluntary intake and digestibility and consequent weight loss of animals, and poor economic return of the venture. The scarcity of forages during the dry seasons has also been reported to cause communal conflicts between the nomads and arable farmers (Lamidi and Ologbose, 2014).

Crop-livestock farming is an integrated agricultural production system in which crop products especially wastes can be used as feed resources for the animals. Meanwhile, the dung and urine of the animals can also be used to improve the soil fertility. Increase in crop production will consequently lead to increase in the production of crop waste which can be harnessed or transformed to feed resources for animal production. The best way to maximally utilize crop wastes is to convert them to useful materials such as feed resources for animals, especially ruminant animals. Silage production has been used as a means of adding value to different crops waste. Silage production has been used as sustainable measures and strategies to ameliorate the dry season feeding challenges. Silage is defined as any plant material that has undergone fermentation or "pickling" in a silo, while silo is any storage structure in which green, moist forage is preserved (Amuda et al., 2019). The primary goal of making silage is to maximize the preservation of original nutrients in the forage crop for feeding of livestock at a later date in livestock feeding programs.

Fortunately, apart from the conventional forage crops, materials that can be ensiled include fodder crops and crop residues or by-products ('t Mannetje, 2000). Silage production has been used as a means of adding value to different crops waste.

Maize stover is the left over material when maize cob has been harvested by the farmers. It can be a waste if left on the farm to dry off, it can also be ploughed back into the soil or destroyed by rodents or insect especially termites. Groundnut haulms is the entire groundnut plant after groundnut were removed after harvesting, it is made 


\section{Lamidi and Ingweye}

up of the leaves, stem and root. It is also crop wastes which were left on the farm. Sometimes it may be used as hay; and where weather is not favorable, it is left on the farm and wasted. Groundnut haulms have a higher crude protein content (11$17 \%$ ) compared to $2-8 \%$ in cereal residues. Addass et al. (2011) reported 91\% DM, $8.30 \%$ ash, $10.90 \% \mathrm{CP}, 31.80 \mathrm{CF}$ and $1.31 \% \mathrm{EE}$ for groundnut haulms. This study assessed the physical quality, nutritional value of ensiled fresh maize stover and fresh groundnut haulms for sustainable ruminant production.

\section{Materials and methods \\ Experimental site}

The study was carried out at Forage Science Laboratory, Department of Animal science, Faculty of Agriculture, University of Port Harcourt, Rivers State. Port Harcourt is a coastal city located in the Niger Delta region of Nigeria within latitudes $6^{\circ} 58^{\prime}-7^{\circ}$ $60^{\prime} \mathrm{E}$ and longitudes $4^{\circ} 40^{\prime}-4^{\circ} 55^{\prime} \mathrm{N}$. The monthly rainfall in Port Harcourt follows a sequence of increase from March to October before decreasing in the dry season months of November to February (Uko and Tamunobereton, 2013; Lamidi and Ogunkunle, 2016).

Collection of experimental materials and silage production

Fresh maize stover was collected from the Faculty of Agriculture Demonstration Farm immediately after maize cobs were harvested, also fresh groundnut haulms were gathered after groundnut seeds were harvested from the groundnut plant, the haulms cleaned of soil from the root. Both the fresh crop wastes (maize stover and groundnut haulms) were allowed to wilt for 2-3 days.

The wilted maize stover and groundnut haulms were chopped to 3 - $5 \mathrm{~cm}$ with forage chopper machine separately and later weighed on percentage bases as follows:

$\mathrm{T} 1=100 \%$ of Maize stover

$\mathrm{T} 2=100 \%$ of Groundnut haulm

$\mathrm{T} 3=50 \%$ of Maize stover: $50 \%$ of Groundnut haulm.

The experimental materials were ensiled in laboratory bottles $\left(\right.$ Bamma $\left.^{\circledR} 960 \mathrm{ml}\right)$ as laboratory silos and plastic drum for preferential trial. The silos were tightly tied and covered to avoid air penetration. Each treatment had four replicates and the ensiled materials were kept at room temperature of 28 to $32^{\circ} \mathrm{C}$ for 30 days.

\section{Data collection}

Physical characteristics as well as temperature $\left({ }^{\circ} \mathrm{C}\right)$ and $\mathrm{pH}$ of the silage were determined immediately the silos were opened. Physical characteristics of silage for ensiled fresh maize stover and groundnut haulms were carried out according to the procedures of Lamidi and Akhigbe (2018), while $\mathrm{pH}$ and temperature were determined using Digital $\mathrm{pH}$ Meter. Sub-samples of the silage were oven-dried, ground with a Thomas Willey Laboratory Mill-Model 4 to pass through $1 \mathrm{~mm}$ sieve.

\section{Chemical analysis}

\section{Proximate composition}

The dry matter, crude protein, ether extract and Ash contents of the milled silage sample were determined according to A.O.A.C. (2000). Non-fibre carbohydrate was calculated as NFC $=100-(\mathrm{CP}+\mathrm{Ash}+$ $\mathrm{EE}+\mathrm{NDF}$ ).

\section{Fibre fraction analysis}

Neutral detergent fibre (NDF), Acid detergent fibre (ADF) and Acid detergent lignin (ADL) of the milled grass sample were determined with the procedure of Van Soest et al. (1991). Cellulose content was taken as the difference between ADF and ADL while hemicellulose content was also calculated as the difference between NDF and ADF.

\section{Anti-nutritional factors}

Tannin and saponin contents were 
determined according to the methods described by Lamidi and Ogunkunle, (2015). Oxalate was according to Munro (2000) while phytate was determined as described by Prokopet and Unlenbruck (2002).

\section{In vitro digestibility trial}

The in vitro trial was carried out at the laboratory of Department of Animal Science, University of Benin, Benin City, Edo State, Nigeria. The method adopted was as described by Bamikole et al. (2019). The modified in vitro fermentation procedure of Navarro-Villa et al. (2011) was adopted as described by Bamikole et al. (2019). A phosphate - bicarbonate buffer (Mould et al., 2005) used (g/L) were: 1.98 $\mathrm{Na}_{2} \mathrm{HPO} 4.12 \mathrm{H}_{2} \mathrm{O}, 1.302 \quad \mathrm{KH}_{2} \mathrm{PO}_{4}, 0.105$ $\mathrm{MgCl}_{2} \cdot 6 \mathrm{H}_{2} \mathrm{O}, 1.407 \quad \mathrm{NH}_{4} \mathrm{HCO}_{3}, 5.418$ $\mathrm{NaOH}$. Rumen fluid was obtained from three fistulated goats before morning feeding into a thermos flask and taken to the laboratory where it was strained through four layer of Cheesecloth under continuous flushing with $\mathrm{CO}_{2}$. Inoculum for incubation was prepared using ratio of rumen fluid to buffer of 1:2. $190 \mathrm{mg}$ of substrate (mixture of equal proportion ground maize, Guinea grass and Centrosema molle) was weighed with $10 \mathrm{mg}$ of the test material (experimental treatments) into nylon bags, sealed and incubated using $30 \mathrm{ml}$ of inoculum in $100 \mathrm{Ml}$ graduated syringes at $30^{\circ} \mathrm{C}$ for $24 \mathrm{hrs}$. Syringes containing only the substrate (i.e. without the experimental treatments) and those containing only the inoculum (i.e. without sample) represent the control and blank respectively. Gas production (i.e. accumulated gas in the head space of each fermentation syringe) was read 3 hourly for 24 hours to know the volume of gas produced. At the end of incubation, $4 \mathrm{~mL}$ of $10 \mathrm{M} \mathrm{NaOH}$ was introduced into the headspace of the syringes for methane determination. The bags with the residue were removed from the syringes, rinsed thoroughly with water and dried at $100^{\circ} \mathrm{C}$ for $24 \mathrm{~h}$, and then to constant weight to determine in vitro dry matter disappearance (IDMD).

\section{Calculation for post incubation parameters}

Organic matter digestibility (OMD) was estimated as: $\mathrm{OMD}=14.88+0.889 \mathrm{GV}+$ $0.45 \mathrm{CP}+0.651$ ash (Menke and Steingass, 1988).

Short-chain fatty acids (SCFA) were estimated as: SCFA $=0.0239 \mathrm{GV}-0.0601$ (Getachew et al., 1999).

Metabolizable energy (ME) was calculated as: $\mathrm{ME}=2.20+0.136 \mathrm{GV}+0.057 \mathrm{CP}+$ 0.00029 CF (Menke and Steingass, 1988).

Fermentation Efficiency (FE) was calculated as: Fermentation Efficiency (FE) $=$ Dry matter Digestibility $(\mathrm{g} / \mathrm{kg}) /$ Total Gas Volume $(\mathrm{mL} / \mathrm{g})$.

\section{Nutritive values parameters calculations}

Nutritive parameters such as Dry matter intake (DMI), Digestible dry matter (DDM) and Relative feed value (RFV) were calculated as follows: $\mathrm{DMI}=(120 \div \mathrm{NDF} \%$ dry matter basis $), \mathrm{DDM}=88.9-(0.779 \mathrm{x}$ $\mathrm{ADF} \%$ dry matter basis $), \mathrm{RFV}=(\mathrm{DDM} \% \mathrm{x}$ $\mathrm{DMI} \% \mathrm{x}$ 0.775) (Horrock and Valentine, 1999; Baba et al., 2018).

\section{Data analysis}

The experimental design was a completely randomized design (CRD), in which the experimental treatments were the only source of variability.

The statistical model is as follows: $\mathrm{Xij}=\mu+$ $\mathrm{Ti}+\sum \mathrm{ij}$

Where $\mathrm{Xij}=$ value of observation; $\mu=$ population mean; $\mathrm{Ti}=$ treatment effect; $\Sigma$ $\mathrm{ij}=$ error term

All data obtained were subjected to the analysis of variance (ANOVA). Means were separated using Least Significant Difference (LSD) SAS (1999) package. 


\section{Lamidi and Ingweye}

\section{Results and discussion}

Table 1 shows the physical features of ensiled maize stover and groundnut haulms. The colour of the silage were cream, greenish brown and light brown for $\mathrm{T} 1, \mathrm{~T} 2$ and $\mathrm{T} 3$, respectively. Texture was smooth for $\mathrm{T} 1$ and coarse for $\mathrm{T} 2$ and slightly coarse for T3. All the silages were moist with pleasant aroma. The $\mathrm{pH}$ and temperature value ranged from $3-4.5$ and $30-31.5^{\circ} \mathrm{C}$, respectively.

The colour of the silage was close to the original colour of the grass. This was an indication of good quality silage that was well preserved (Oduguwa et al., 2007). The range of $\mathrm{pH}$ value $(3-4.5)$ recorded in this study was within the value $(3.81-4.90)$ reported by Akinbode et al. (2017) when sugarcane top was ensiled with broiler litter. Generally, the mild sweet aroma perceived in all the silage is an indication of normal physical characteristics of good silage (Lamidi and Akhigbe, 2018).

Table 1: Physical features of ensiled maize stover and groundnut haulms

\begin{tabular}{llll}
\hline & \multicolumn{2}{l}{ Experimental treatments } & T3 \\
\cline { 2 - 4 } Parameters & T1 & T2 & Light brown \\
Colour & Cream & Greenish brown & Slightly coarse \\
Texture & Smooth & Coarse & Moist \\
Wetness & Moist & Moist & Mild sweet \\
Aroma & Mild sweet & Mild sweet & 4.5 \\
pH & 3.5 & 3 & 31.5 \\
Temperature $\left({ }^{0} \mathrm{c}\right)$ & 32 & 30 & No mould \\
Mouldiness & No mould & No mould & groundnut haulms.
\end{tabular}

The proximate composition and fibre fractions of ensiled fresh maize stover and groundnut haulms in wet season are shown in Table 2. There were significant differences $(\mathrm{P}<0.05)$ in all the proximate composition and fiber fractions of the silage across the experimental treatments. The T3 had highest $(\mathrm{P}<0.05)$ content for proximate composition and fiber fractions except the hemicellulose which was similar $(\mathrm{P}>0.05)$ in $\mathrm{T} 2$ and $\mathrm{T} 3$. The $\mathrm{CP}$ contents of the silage $(11.67-12.67 \%)$ were above the critical lower limit $(7 \% \mathrm{CP})$ which forage intake by ruminants and rumen microbial activity could be negatively affected (Norton, 2003). It implies that the silage would provide the adequate nitrogen requirement for the rumen microorganisms to maximally digest the main components of dietary fibre leading to the production of volatile fatty acids (Lamidi and Ogunkunle, 2016), which in turn facilitates microbial protein synthesis (Lamidi and Aina, 2013) and improve the production of meat, milk, skin and hide for man uses. Higher levels of NDF and lignin have been reported to have negative effect on DM intake and digestibility (Bakshi and Wadhwa, 2004). However, the NDF (47.39-51.15\%) values observed for the silage were less than $60 \%$ which is considered safe for acceptable intakes of forage in ruminants (Meissner et al., 1991).

Mineral profile of ensiled maize stover and groundnut haulms is shown in Table 3 . There was a significant difference $(\mathrm{P}<0.05)$ in the minerals content of the silage across the experimental treatments. The T3 had higher $(\mathrm{P}<0.05)$ content of the minerals analyzed, followed by $\mathrm{T} 2$ and $\mathrm{T} 1$ recorded least $(\mathrm{P}<0.05)$ contents of minerals. The $\mathrm{Ca}$, $\mathrm{P}, \mathrm{K}, \mathrm{Na}, \mathrm{Mg}, \mathrm{Fe}$ and $\mathrm{Zn}$ contents varies from $0.18-0.20 \%, 0.32-0.36 \%, 0.46-$ $0.51 \%, 0.23-0.27 \%, 0.25-0.29 \%$, $159.78-167.21 \mathrm{mg} / \mathrm{kg}$ and $31.29-34.56$ $\mathrm{mg} / \mathrm{kg}$, respectively. 
Table 2: Proximate composition and fibre fractions of ensiled fresh maize stover and grou ndnut haulms in wet season

\begin{tabular}{|c|c|c|c|c|c|}
\hline \multirow[b]{2}{*}{ Parameters } & \multicolumn{3}{|c|}{ Experimental treatments } & \multirow[b]{2}{*}{ SEM } & \multirow[b]{2}{*}{ LOS } \\
\hline & T1 & T2 & T3 & & \\
\hline Dry matter & $86.96^{\mathrm{b}}$ & $87.07^{\mathrm{b}}$ & $87.24^{\mathrm{a}}$ & 0.05 & ** \\
\hline Crude protein & $11.67^{\mathrm{c}}$ & $12.18^{\mathrm{b}}$ & $12.69^{\mathrm{a}}$ & 0.15 & ** \\
\hline Ether extract & $2.12^{\mathrm{c}}$ & $2.23^{\mathrm{b}}$ & $2.37^{\mathrm{a}}$ & 0.04 & ** \\
\hline Crude fibre & $13.21^{\mathrm{c}}$ & $13.35^{\mathrm{b}}$ & $13.67^{\mathrm{a}}$ & 0.07 & ** \\
\hline Ash & $6.56^{\mathrm{c}}$ & $6.78^{\mathrm{b}}$ & $6.89^{\mathrm{a}}$ & 0.05 & ** \\
\hline Neutral detergent fibre & $47.39^{c}$ & $49.23^{\mathrm{b}}$ & $51.15^{\mathrm{a}}$ & 0.54 & ** \\
\hline Acid detergent fibre & $25.67^{\mathrm{c}}$ & $27.12^{\mathrm{b}}$ & $29.05^{\mathrm{a}}$ & 1.35 & $* *$ \\
\hline Nitrogen free extract & $52.33^{\mathrm{b}}$ & $52.47^{\mathrm{b}}$ & $51.15^{\mathrm{a}}$ & 0.07 & $* *$ \\
\hline Acid detergent lignin & $8.59^{\mathrm{c}}$ & $8.76^{\mathrm{b}}$ & $9.23^{\mathrm{a}}$ & 1.00 & $* *$ \\
\hline Cellulose & $17.75^{\mathrm{c}}$ & $18.36^{\mathrm{b}}$ & $19.82^{\mathrm{a}}$ & 0.36 & ** \\
\hline Hemicellulose & $21.72^{\mathrm{b}}$ & $22.10^{\mathrm{a}}$ & $22.11^{\mathrm{a}}$ & 0.07 & $* *$ \\
\hline
\end{tabular}

$\overline{a, b, c}$ Means on the same row with different superscripts differ significantly $(\mathrm{P}<0.05)$.

$\mathrm{SEM}=$ standard error of mean; $\mathrm{T} 1=100 \%$ Maize stover; $\mathrm{T} 2=100 \%$ Groundnut haulms; $\mathrm{T} 3=50 \%$ Maize stover $+50 \%$ Groundnut haulms; LOS= level of significant.

The Ca recorded for the silage in this study $(0.18-0.20 \%)$ was within the recommended range $(0.20-0.26 \mathrm{~g} / 100 \mathrm{~g})$ for maintenance of growing and lactating sheep (Reuter and Robinson, 1997) while P content $(0.32-0.36 \%)$ was also within the recommended range $(0.15-0.48 \mathrm{~g} / 100 \mathrm{~g})$ required by ruminants (McDowell, 1997).
The $\mathrm{Mg}$ content of the silage was in line with the recommended range $(0.25-0.29$ $\%$ ) for ruminant animals (McDowell, 1997). This is an indication that the silage i.e. ensilaged fresh maize stover and groundnut haulms will supply the required minerals for body metabolism for ruminant animal without mineral fortification.

Table 3: Mineral profile of ensiled maize stover and groundnut haulms

\begin{tabular}{llllll}
\hline \multirow{2}{*}{ Parameters } & \multicolumn{3}{c}{ Experimental treatments } & SEM & LOS \\
\cline { 2 - 6 } & $\mathrm{T} 1$ & $\mathrm{~T} 2$ & $0.20^{\mathrm{a}}$ & 0.00 & $* *$ \\
Calcium & $0.18^{\mathrm{b}}$ & $0.19^{\mathrm{a}}$ & $0.36^{\mathrm{a}}$ & 0.01 & $* *$ \\
Phosphorus & $0.32^{\mathrm{c}}$ & $0.34^{\mathrm{b}}$ & $0.51^{\mathrm{a}}$ & 0.01 & $* *$ \\
Potassium & $0.46^{\mathrm{c}}$ & $0.49^{\mathrm{b}}$ & $0.27^{\mathrm{a}}$ & 0.01 & $* *$ \\
Sodium & $0.23^{\mathrm{c}}$ & $0.26^{\mathrm{b}}$ & $0.29^{\mathrm{a}}$ & 0.01 & $* *$ \\
Magnesium & $0.25^{\mathrm{c}}$ & $0.28^{\mathrm{b}}$ & $167.21^{\mathrm{a}}$ & 1.08 & $* *$ \\
Iron & $159.78^{\mathrm{c}}$ & $164.46^{\mathrm{b}}$ & $34.56^{\mathrm{a}}$ & 0.51 & $* *$ \\
Zinc & $31.29^{\mathrm{c}}$ & $34.15^{\mathrm{b}}$ & & &
\end{tabular}

$\overline{a, b, c}$ Means on the same row with different superscripts differ significantly $(\mathrm{P}<0.05)$.

$\mathrm{SEM}=$ standard error of mean; T1 $=100 \%$ Maize stover; T2=100\% Groundnut haulms; T3=50\% Maize stover $+50 \%$ Groundnut haulms; LOS= level of significant.

Table 4 shows the anti-nutritional factors of ensiled fresh maize stover and groundnut haulms. There was a significant difference $(\mathrm{P}<0.05)$ in the anti-nutritional factors across the experimental treatments. The $\mathrm{T} 3$ had higher $(\mathrm{P}<0.05)$ contents of all the antinutritional factors. Saponins and tannin were similar $(\mathrm{P}>0.05)$ in $\mathrm{T} 1$ and $\mathrm{T} 2$. The least $(\mathrm{P}<0.05)$ phytate, oxalate and trypsin inhibitor contents was recorded in $\mathrm{T} 1$.
Feedstuff containing saponin has been shown to be defaunating agent (Fajemisin, 2015) and capable of reducing methane production (Babayemi et al., 2004). Diagayete and Hugg (1981) reported that, sheep and cattle can tolerate $2-5 \%$ dietary tannin while Nastis and Malecheck (1981) reported that goats can tolerate about $9 \%$ tannin in their diets. The saponins value recorded for the ensiled fresh maize stover 


\section{Lamidi and Ingweye}

and groundnut haulms in this study were ranged for varieties $(0.40-0.42 \%)$, feedstuff containing saponin had been shown to be defaunating agent (Teferedegne, 2000) and capable of reducing methane production (Babayemi et al., 2004). Alalade et al. (2019) reported that saponin have effect on erythrocyte haemolysis, reduction of blood and liver cholesterol, depression of growth rate, bloat (ruminant) inhibition of smooth muscle activity, enzyme inhibition and reduction in nutrient absorption. Saponin have been reported to alter cell wall permeability and therefore to produce some toxic effect when ingested (Belmar et al., 1999). Oxalates bind calcium and are excrete through urine or form crystals which might cause kidney stones (Kubkomawa et al., 2016).

Table 4: Anti-nutritional factors of ensiled fresh maize stover and groundnut haulms in wet season

\begin{tabular}{llllll}
\hline & \multicolumn{5}{c}{ Experimental treatments } \\
\cline { 2 - 6 } Parameters & $\mathrm{T} 1$ & $\mathrm{~T} 2$ & $\mathrm{~T} 3$ & SEM & LOS \\
\hline Phytate (\%) & $0.20^{\mathrm{c}}$ & $0.22^{\mathrm{b}}$ & $0.23^{\mathrm{a}}$ & 0.00 & $* *$ \\
Oxalate (\%) & $0.16^{\mathrm{c}}$ & $0.18^{\mathrm{b}}$ & $0.19^{\mathrm{a}}$ & 0.00 & $* *$ \\
Tannin (\%) & $0.18^{\mathrm{b}}$ & $0.18^{\mathrm{b}}$ & $0.19^{\mathrm{a}}$ & 0.00 & $* *$ \\
Saponins (\%) & $0.40^{\mathrm{b}}$ & $0.40^{\mathrm{b}}$ & $0.42^{\mathrm{a}}$ & 0.00 & $* *$ \\
Trypsin inhibitor (mg/g) & $1.97^{\mathrm{c}}$ & $2.26^{\mathrm{b}}$ & $2.38^{\mathrm{a}}$ & 0.01 & $* *$ \\
\hline
\end{tabular}

a, b, c Means on the same row with different superscripts differ significantly $(\mathrm{P}<0.05)$.

$\mathrm{SEM}=$ standard error of mean; $\mathrm{T} 1=100 \%$ Maize stover; $\mathrm{T} 2=100 \%$ Groundnut haulms; $\mathrm{T} 3=50 \%$ Maize stover $+50 \%$ Groundnut haulms; LOS= level of significant.

Table 5 shows the post in-vitro digestibility characteristics of ensiled maize stover and groundnut haulms. There were significant differences $(\mathrm{P}<0.05)$ in all the post in-vitro digestibility parameters observed across the experimental treatments. The T3 had highest $(\mathrm{P}<0.05)$ value for all the parameters considered except ME which was similar in $\mathrm{T} 2$ and $\mathrm{T} 3$. The value recorded for methane $\left(\mathrm{CH}_{4}\right)$ production ranges from $10.33-14.00$, methane and gas volume ratio $\left(\mathrm{CH}_{4} \mathrm{GV}\right)$, In-vitro dry matter digestibility (\%) (IDMD), Fermentation efficiency (FE), $\mathrm{CH}_{4}$ reduction (\%), Short chain fatty acid (SCFA), Metabolizable energy (ME) and In-vitro organic matter digestibility (\%) (IOMD) were $0.65-0.83$, $39.33-71.83 \%, 2.37-4.30,84.61-$ $88.64 \%, 0.23-0.40,4.54-5.53$, and 35.75 $-41.43 \%$, respectively.

Meanwhile, the higher SCFA $(0.40(\mu \mathrm{M}))$ and $\mathrm{ME}(5.53 \mathrm{MJ} / \mathrm{kg} / \mathrm{DM})$ recorded for T3(50\% Maize stover $+50 \%$ Groundnut haulms) is an indication that the silage has a potential to make energy available to ruminant. This observation correlates with the report of Ajayi (2007) that higher SCFA or VFA such as butyrate and acetate suggest a potential to make energy available to ruminant. The estimation of the Metabolizable energy (ME) values is valuable for purposes of ration formulation and to set economic value of feed for other purposes (Akinyemi et al., 2019). It is also a good index for measuring the quality of feeds particularly forages.

Table 6 shows the dry matter intake, digestible dry matter, and relative feed value for ensiled fresh maize stover and groundnut haulms. Similar $(\mathrm{P}>0.5)$ feeding value were recorded in the nutritive value (Dry matter intake, digestible dry matter, and relative feed value) of the experimental treatments. The values observed for DMI, DDM and RFV ranges from $2.44-2.45$, $67.62-67.67$ and 127.86 - 127.98, respectively. 
Table 5: Post in-vitro digestibility of ensiled fresh maize stover and groundnut haulms

\begin{tabular}{|c|c|c|c|c|c|}
\hline \multirow[b]{2}{*}{ Parameters } & \multicolumn{3}{|c|}{ Treatments } & \multirow[b]{2}{*}{ SEM } & \multirow[b]{2}{*}{$\mathrm{L} / \mathrm{S}$} \\
\hline & $\mathrm{T} 1$ & $\mathrm{~T} 2$ & T3 & & \\
\hline $\mathrm{CH}_{4}$ & $10.33^{\mathrm{b}}$ & $10.67^{b}$ & $14.00^{\mathrm{a}}$ & 1.23 & $* *$ \\
\hline $\mathrm{CH}_{4} \mathrm{GV}$ & $0.65^{\mathrm{b}}$ & $0.72^{\mathrm{b}}$ & $0.83^{\mathrm{a}}$ & 0.52 & $* *$ \\
\hline In-vitro dry matter digestibility (\%) & $39.33^{\mathrm{c}}$ & $51.77^{\mathrm{b}}$ & $71.83^{\mathrm{a}}$ & 6.62 & $* *$ \\
\hline Fermentation efficiency & $2.37^{\mathrm{c}}$ & $3.88^{\mathrm{b}}$ & $4.30^{\mathrm{a}}$ & 0.44 & $* *$ \\
\hline Methane reduction(\%) & $84.61^{\mathrm{b}}$ & $88.28^{\mathrm{a}}$ & $88.64^{\mathrm{a}}$ & 1.35 & $* *$ \\
\hline Short chain fatty acid $(\mu \mathrm{M})$ & $0.23^{\mathrm{c}}$ & $0.33^{\mathrm{b}}$ & $0.40^{\mathrm{a}}$ & 0.04 & $* *$ \\
\hline Metabolizable energy (MJ/kg/DM) & $4.54^{b}$ & $5.14^{\mathrm{ab}}$ & $5.53^{\mathrm{a}}$ & 0.21 & $* *$ \\
\hline In-vitro organic matter digestibility $(\%)$ & $35.75^{\mathrm{c}}$ & $39.09^{\mathrm{b}}$ & $41.43^{\mathrm{a}}$ & 1.26 & $* *$ \\
\hline
\end{tabular}

Table 6: Dry matter intake, digestible dry matter, and relative feed value for ensiled fresh maize stover and groundnut haulms

\begin{tabular}{llllll}
\hline & \multicolumn{3}{c}{ Experimental treatments } \\
\cline { 2 - 6 } Parameters & T1 & T2 & T3 & SEM & L/S \\
\hline Dry matter intake & 2.45 & 2.44 & 2.44 & 0.027 & $\mathrm{~N} / \mathrm{S}$ \\
Digestibility dry matter & 67.62 & 67.65 & 67.67 & 0.381 & $\mathrm{~N} / \mathrm{S}$ \\
Relative feed value & 127.86 & 127.94 & 127.98 & 2.105 & $\mathrm{~N} / \mathrm{S}$ \\
\hline
\end{tabular}

a, b, c Means on the same row with the same superscripts not differ significantly $(\mathrm{P}>0.05)$.

$\mathrm{SEM}=$ standard error of mean; $\mathrm{T} 1=100 \%$ Maize stover; $\mathrm{T} 2=100 \%$ Groundnut haulms; $\mathrm{T} 3=50 \%$ Maize stover $+50 \%$ Groundnut haulms; LOS= level of significant; N/S= Not significant

The similarity might be attributed to the contents of the proximate composition e.g. $\mathrm{CP}$ which was above the $7 \%$ required for rumen microbe and the moderate value recoded for NDF. This is corroborated by the report of Lamidi et al. (2019b) who viewed similar value recorded for DMI, DDM and RFV in the experimental treatments within the context of ADF and NDF levels. The similarity observed for the nutritive value is an indication that the experimental treatments have the potential to be used as feed resources for ruminant animals.

\section{Conclusion}

Conclusively, the silage exhibited good physical features, appropriate proximate composition, fibre fractions without deleterious anti-nutritional factors and post in-vitro digestibility characteristics that justified its potential in solving the challenges of dry season feed for ruminant production. Meanwhile, the similarity of nutritive value for the experimental treatments further proof that the silages (T1, $\mathrm{T} 2$ and T3) have the potential to mitigate the challenges of dry season feeding. Treatment 3 (50\% maize stover and 50\% groundnut haulms) is recommended for ruminant farmers.

\section{References}

Addass, P. A., Nyako, H. D., Agga. D. P., Mohammed, I. D., Midau, A., Fintan, J. S. and Ja'afar-Furo, M. R. 2011. Nutrients evaluation of some common feed resources for cost effective feeding of ruminants in Mubi, Nigeria. Agriculture and Biology Journal of North America. 2(1): 15-18.

Ajayi, F. T. 2007. Nutritional evaluation of Panicum maximum intercropped with some legumes for West African Dwarf goats. Ph.D. Thesis University of Ibadan, Ibadan, Nigeria. Animal Feed science and 
technology 123 124; $197-210$.

Akinbode, R. M., Isah, O. A., Oni, A. O., Arigbede, O. M., and Ojo, V. O. A. 2017. Nutritional evaluation of sugarcane top ensiled with varying proportion of broiler litter. Livestock Research for Rural Development 29 (1) 2017.

AOAC (Association of Analytical Chemists). 2000. Official Methods of Analysis, $17^{\text {th }}$ ed. Association of Analytical Chemists. Washington, DC.

Alalade, J. A., Fabule, S. A., Aderinola, O.A., Fajemisin, A. N., Okunlola, O. O., Olayemi, W. A. and Adebisi, I. A. 2019. Proximate composition and anti nutritional content of hydroponically grown fodder from maize (Zea mays) and sorghum (Sorghum bicolour). Proceedings at the 3rd Biennial Conference of the Society for Grassland and Development in Nigeria held at the National Animal Production Research Institute, A.B.U - Shika, Zaria. 3rd - 6th Nov. 2019. Pp. $12-15$.

Akinyemi, B. T., Uzor, C. M, Dele, P. A., Okukenu O. A. and Jolaosho, A. O. 2019. In Vitro Digestibility of mixtures of Guinea grass silage, selected browse plants and dried cassava peels. Proceedings at the 3rd Biennial Conference of the Society for Grassland and Development in Nigeria held at the National Animal Production Research Institute, A.B.U - Shika, Zaria. 3rd - 6th Nov. 2019. Pp. 138 $-142$.

Amuda J. T., Falola, O. O. and Tukura, D. M. 2019. Assessment of ensiled millet stover with or without legumes stover for quality and acceptability by west African
Dwarf goat. Proceedings at the $44^{\text {th }}$

Annual Conference of the Nigerian Society of Animal Production held at University of Abuja, Pg. 321 324.

Baba, M., Nasir, A., Kabiru, A., Erakpotobor, M., and Umar, G. A. 2018. Effects of additives and their levels of inclusion on nutritive value of silage made from elephant grass (Pennisetum purpureum). Nigerian Journal Animal Production, 45: 354-362.

Babayemi, O. J., Demeyer, D. and Fievez, V. 2004. In vitro fermentation of tropical brows seed in relation of their content of secondary metabolize. Journal of Animal Feed Science and Technology, 1: 31-34.

Bakshi, M. P. S. and Wadhwa, M. 2004. Evaluation of forest leaves of semihilly arid region as

livestock feed. Asian-Australasian Journal of Animal Science. 95, 93- 104.

Bamikole, M. A., Babayemi, O. J., Lamidi, A. A., Ayinde, B. A., Ikhatua, U. J., Ojeaga, S., Ezemba, T. and Alaita, O. 2019. Preliminary in vitro screening of some spice and medicinal plants from Edo and Rivers State, Nigeria for reducing enteric methane production in ruminants. Nigerian Journal of Animal Production. 46(2): $258-268$.

Belmar, R., Nava-Montero, R., Sandoval-Castro, C., McNab, J. M. 1999. Jack bean (Canavalia ensiformis L. DC) in poultry diets: Anti-nutritional factors and detoxification studies - a review. World Poultry Science Journal, 55 (1): 37-59.

Diagayete, M. and Hugg, W. 1981. Tannin contents of African Pasture Plants: 
Effects on Analytical Data and invitro digestibility. Animal Research and Development, 15: 79 -80 .

Getachew, G., Makkar, H. P. S. and Becker, K. 1999. Stoichiometric relationship between short chain fatty acid and in vitro production in presence and absence of polyethylene glycol for tannin containing browses, EAAP Satellite Symposium, Gas production; fermentation kinetics for feed evaluation and to assess microbial activity 18 - 19 August, Wageningen, The Netherlands.

Horrocks and Vallentine, J. F. 1999. Harvested forages. London, UK: Academic Press. p. 13.

Kubkomawa, I. H., Obasi, I. U. and Esonu, B. O. 2016. The use of cassava leaves as human food and livestock feed. (Eds) I. C. Okoli and A. B. I. Udedibie. Proceedings of a NIPOFERD Workshop on "Knowledge Transfer towards Cost-Effective Poultry feed production from processed cassava products to improve the productivity of small-scale famers in Nigeria" June 27 - July 1, 2016, Asaba, Nigeria. Pp.103-129.

Lamidi, A. A., Aina, A. B. J, Sowande, S. O. and Jolaosho, A. O. 2009. Assessment of Panicum maximum (Jacq), Gliricidia sepium (Jacq) and Gmelina arborea (Roxb) based as all year round feed for West African Dwarf Goat. In: Akinlade et al (Eds) Global Economic Recession and Challenges to Livestock Production in Nigeria. In Proceeding of Animal Science Association of Nigeria (ASAN). Held at the Ladoke Akintola
University Technology, Ogbomosho. 14th to 17 th September 2009. pp 582 to 584 .

Lamidi, A. A. and Aina, A. B. J. 2013. Presowing treatment, agronomic parameters and nutritive potential of Tephrosia bracteolata (Guill. Et Perr.) at four different stages of growth. African Journal of Livestock Extension, 11:31-36.

Lamidi, A. A. and Ologbose, F. I. 2014.

Dry Season Feeds and Feeding: A Treat to Sustainable Ruminant Animal Production in Nigeria. Journal of Agriculture and Social Research, Vol. 14(1). Pp. 18-31.

Lamidi, A. A. and Ogunkunle, T. 2015. Chemical composition, Mineral profile and phytochemical properties of common feed resources used for small ruminant animal production in South-West, Nigeria. International Journal of Science and Nature, 6(1): 92-96.

Lamidi, A. A. and Ogunkunle, T. 2016. Nutritional potential of poultry dropping meal as feed resources for ruminant production in Niger Delta. Nigeria. Global Agricultural Science \& Technology. 1:1-11.

Lamidi, A. A. and Akhigbe, J. 2018. Quality of ensiled guinea grass (Panicum maximum) at varying proportions with sweet potato peels for sustainable ruminant production in Niger Delta, Nigeria. Nigerian Journal of Animal Production. Volume 45(45). 184 191

Lamidi, A. A., Etela, I., Ingweye, J. N., Ologbose, F. I., Osarobundo, E. N., and Ishiaku, Y. M. 2019a. Nutrients profile and in vitro fermentation characteristics of Centrosema pascuorum at four different cutting regimes in Niger 
Delta, Nigeria. Proceedings of 3rd Biennial Conference of Society for Grassland Research and Development in Nigeria (SOGREDEN) Held at National Animal Production Research Institute (NAPRI) Shika, Zaria, Kaduna State. 3rd - 6th November, 2019. Pp. $92-99$.

Lamidi, A. A., Wilson, J. I. and Joseph, O. O. 2019b. Chemical constituents and in-vitro rumen fermentation for dietary inclusion of Delonix regia seed meal for sustainable ruminant production. Nigerian Journal of Animal Production, 46(5):172-181.

McDowell, L. R. 1996. Feeding minerals to cattle in pasture. Animal Feed Science Technology, 60:241.

Menke, K. H., and Steingass, H. 1988. Estimation of the energetic feed value from chemical analysis and in vitro gas production using rumen fluid. Animal Research Development, 28: 7-55.

Meissner, H. H., Koster, H. H, Nieuwoudt, S. H., Coertze, R. J. 1991. Effect of energy supplementation on intake and digestion of early and mid-season rye grass and Panicum/smuts finger hay and in sacco disappearance of various forage species. South African Journal of Animal Science. 21: 33-42.

Mould, F. L., Morgan, R., Kliem, K. E., Krystallidon, E. 2005. A review and simplification of in vitro incubation medium. Animal Feed Science Technology. 123 - 124, $155-172$.

Nastis, A. S. and Matechek, J. C. 1981. Digestion and Utilization of nutrients Oak browse by goats. Journal of Animal Science, 52:
$283-288$.

Navarro Villa, A., O'Brien, M. Lopez, S., Boland, T. M. and O'Kiely, P. 2011. Modifications of gas production technique for assessing in vitro rumen methane production from feedstuff. Animal Feed Science and Technology. 166 $167,163-174$.

Norton, B. W. 2003. The nutritive value of trees legumes as dietary supplement for ruminants. In: Forage tree legumes in tropical agriculture. Gutterridge, R. C. and Shetton, H.M. (Eds). Pp.171- 191.

Odugwua, B. O., Jolaosho, A. O. and Ayankoso. M. T. 2007. Effect of ensiling on the physical properties, chemical composition and mineral content of Guinea grass and cassava tops silage. Nigerian Journal of Animal Production 34: 100-106.

Prokopet, G. and Unlenbruck, K. W. 2002. Protectine eine nen kalsse anti-kwoperahlich verbindungen dish. Ges. Heit. 23:318.

Reuter, D. J. and Robinson, J. B. 1997. Plant Analysis. An Interpretation Manual. $2^{\text {nd }}$ edition. CSIRO Publishing: Melbourne.

SAS .2002. Statistical Analysis System, Computer Software, SAS/STAT User's Guide Version 9, Statistical Analysis Systems Institute, Cary, North Carolina, 0013402001, USA.

Teferedegne, B. 2000. New perspectives on the use of tropical plants to improve ruminant nutrition. Proceeding of Nutrition Society. 59: $209-214$.

' Mannetje, L. 1999. Introduction to the Conference on Silage Making in the Tropics. In Proc. FAO e-Conf. on Trop. Silage, FAO Plant Prod. 
Physiochemical quality and nutritional value of ensiled fresh maize stover and groundnut haulms

and Protect. Paper 161. 1 Sept. - 15

Dec. 1999, edited by L.'t Mannetje.

Paper 1.0: 1-3.

Uko, E. D. and Tamunobereton-Ari, I. 2013. Variability of Climatic Parameters in Port Harcourt, Nigeria. Journal of Emerging Trends in Engineering and Applied Sciences. 4(5): 727-730.

Received: $24^{\text {th }}$ August, 2020

Accepted: $20^{\text {th }}$ December, 2020 